\title{
China's Sudan Engagement: Changing Northern and Southern Political Trajectories in Peace and War*
}

Daniel Large

\begin{abstract}
China has developed a more consequential role in Sudan over the past two decades, during which it has become bound up in the combination of enduring violent internal instability and protracted external adversity that has characterized the politics of the central state since the 1989 Islamist revolution. Two inter-related political trajectories of China's Sudan engagement are examined here. The first concerns Beijing's relations with the ruling National Congress party in incorporating China into its domestic politics and foreign relations amidst war in Darfur, to which Beijing has responded through a more engaged political role. The second confronts the practical limitations of China's sovereignty doctrine and exclusive reliance upon relations with the central state. Following the peace agreement of 2005 that ended the North-South war, and motivated by political imperatives linked to investment protection concerns, China has developed new relations with the semi-autonomous Government of Southern Sudan, thus seeking to position itself to navigate Sudan's uncertain political future.
\end{abstract}

The official golden jubilee anniversary of diplomatic relations between China and Sudan was formally marked on 4 February 2009, 50 years after Sudan became the fourth diplomatic mission China established in Africa. A month later, on 4 March, the anniversary celebrations were comprehensively overshadowed when Pre-Trial Chamber I of the International Criminal Court, issuing its first ever arrest warrant for a serving president, accused Sudan's President Omar Hassan al-Bashir of five counts of crimes against humanity and two counts of war crimes. External coverage of these two historic events exemplified and continued the prevailing contrast between Sudan as an issue in China's African and international relations and China's engagement within Sudan. China's relations with Sudan have been a prominent part of its recent international politics,

* Special thanks are due to Martha Saavedra, Jago Salmon, Thorsten Benner and Ricardo Soares de Oliveira for their comments on an earlier version of this article. Responsibility for any errors or mistakes remains my own. 
most conspicuously in the build-up to the 2008 Beijing Olympics, but China has also developed a more established, consequential role within Sudan. This has received less attention, apart from such episodes as the killing of five Chinese oil workers in October 2008 by rebel forces in Sudan's Southern Kordofan region, which highlighted the distance between official narratives of golden bilateral relations and the greater complexity of China's involvement in Sudanese politics at large.

This article considers how China's involvement in and relation to Sudanese politics has developed over the past two decades. As the result of a combination of a more established economic position and recurring crises within and outside Sudan, this reflects a basic underlying change in China's Sudan relations. During the Maoist period until the early 1990s, People's China mobilized a "thick" ideological foreign relations rhetoric - of sovereignty, equality, non-interference and solidarity - amidst what was mostly a "thin" content of actual aid, trade and political relations in Sudan. More recently, and especially since the advent of oil investment after the mid-1990s, the expansion of China's relations with Sudan have meant that key foreign policy principles have been spread in a "thinner" manner over a "thickening" content. ${ }^{1}$ The development of increasingly substantive material and political interests has entailed a more politically consequential role for China in Sudan and, in turn, an impact by Sudan on China's international politics. The political evolution of the National Islamic Front since it seized power in 1989 has been central to China's changing engagement. Amidst conflict and instability in Sudan, the government in Khartoum faced protracted external adversity and turned to China as its key international sponsor. For Beijing and Khartoum, in other words, what took off after 1989 as a genuine case of mutual state-to-state benefit largely unencumbered by political complications developed into a more embedded, strategic and multi-stranded engagement. At the same time, the Chinese government has maintained the core principles directing its bilateral relations with Sudan - most importantly sovereignty and non-interference - but these have proved problematic to the point of being inadequate in managing new challenges. Beijing has therefore responded by deepening its political engagement.

The primary aim here is to begin to explore China's role in Sudanese politics by examining two important and inter-related manifestations of China's changing engagement with Northern and Southern Sudan amidst the coexistence of ongoing conflict in Darfur and a formal North-South peace. ${ }^{2}$ The first concerns the development of more complex relations between China and the central state under the National Islamic Front, which was reconstituted as the National Congress Party (NCP). On the one hand, China's support for and association

1 Adapting Michael Walzer's Thick and Thin: Moral Argument at Home and Abroad (Notre Dame: University of Notre Dame Press, 1994).

2 Sudan's impact on Chinese foreign policy and the nature of China's international diplomacy over Darfur are important, closely related questions, but space does not allow proper treatment here. Additionally, knowledge gaps about aspects of China's political relations with Sudan preclude detailed treatment of certain issues at this stage. 
with the governing NCP has rendered it subject to threats within Sudan from organized armed opponents of the central state, necessitating efforts to protect its investment. In foreign policy terms, on the other hand, the NCP's political agency integrated Beijing into its foreign relations manoeuvring with the result that Beijing needed to respond and manage divergent interests with Khartoum. The second manifestation exposes the limitations of China's sovereignty doctrine and its adaptation to new political imperatives. The principle of state sovereignty does not fit well with the nature of changing politics in Sudan and the fact that the central state is unable to exert effective control over all its territory. The Chinese government has had to adapt to these conditions and negotiate a position in Sudanese politics beyond the formally sovereign political centre. The establishment of a semiautonomous government in Southern Sudan after the peace agreement of 2005, reinforced by the possibility of Southern secession after 2011, compelled the development of quasi-sovereign political relations with the Government of Southern Sudan.

\section{A New Actor: China and Sudanese Politics}

Recent attention to China-Sudan relations has tended to privilege Beijing's international diplomacy over Darfur. ${ }^{3}$ Three main contending narratives can be identified that in different ways account for China's evolving Sudan policy. The first and most prominent is a realist explanation identifying China's strategic diplomacy as motivated by defence of economic interests (oil), a function of its energy security imperative, closely connected to power politics and geostrategic competition with the United States. In this logic, which stresses economic causation and power politics, China is a self-interested external power extracting resources for its own benefit and that of a predatory ruling elite. ${ }^{4}$ Chinese accounts alternatively point to American regime-change designs on Sudan or the allied objectives of "political" Western NGOs. The second, broadly social constructivist explanatory strand holds that external advocacy catalysed a normative evolution in Beijing towards a more constructive engagement on Sudan particularly in relation to Darfur: Chinese diplomacy changed from passive, blind support for Khartoum to more active involvement in pressure politics aimed at ending conflict. ${ }^{5}$ Finally, while there are highly critical accounts of China's investment, ${ }^{6}$ official Chinese and official Sudanese positions argue a more classical liberal case in

3 See, for example, Jonathan Holslag, "China's diplomatic manoeuvring on the question of Darfur," Journal of Contemporary China, Vol. 17, No. 54 (2008), pp. 71-84; Chin-Hao Huang, "US China relations and Darfur," Fordham International Law Journal, Vol. 31 (2008), pp. 827-42.

4 For example, Eric Reeves, "China in Sudan: underwriting genocide," testimony before the US-China Economic and Security Review Commission: "China's role in the world: is China a responsible stakeholder?" 3 August 2006.

5 Stephanie Kleine-Ahlbrandt and Andrew Small, "China, the unlikely human rights champion," Policy Innovations (The Carnegie Council, 14 February 2007); and "Beijing's new dictatorship diplomacy," Foreign Affairs, January/February 2008.

6 See, for example, Ali Askouri, "China's investment in Sudan: displacing villages and destroying communities," in Firoze Manji and Stephen Marks (eds.), African Perspectives on China in Africa (Oxford: Fahamu, 2007), pp. 71-86. 
highlighting a positive role, emphasizing the benefits of rising trade and economic growth for peace in Sudan. All positions may account for certain dynamics of China's engagement and raise important issues, but have generally neglected to ground such engagement fully within Sudan. ${ }^{7}$ The ways in which China's involvement has developed within, influenced and itself been affected by Sudanese politics since 1989 is thus worthy of further consideration. ${ }^{8}$

A new phase of Chinese engagement in a longer history of connections with Sudan has unfolded over the past two decades. That China had a minor position in post-colonial Sudanese historiography until recently is indicative of its previously restricted - or "thin" - role in Sudan. ${ }^{9}$ It never amounted to a factor of particular consequence in Sudanese politics until the growth of ties after 1989 in general and the late 1990s, when serious oil operations began, in particular. Contemporary relations are thus deepening a comparatively short history of substantive relations. Prior to oil investment, China's relations with Sudan were, for the most part, more symbolic than politically consequential. Although connected by ancient ties and a colourful colonial past, ${ }^{10}$ and despite a history of Chinese aid, trade and cultural links with Sudan after 1959, China did not play an important part in Sudan's politics and foreign relations after the country's independence in 1956. ${ }^{11}$ This is not to discount history. Nor is it to dismiss the ways in which historical narratives continue to inform - and be mobilized to legitimate - political relations. It is merely to assert that for all the recurring elite

7 The realist position notably discounts the importance of the political principles informing Chinese diplomacy; the constructivist position can convey a misleading teleology of a Chinese shift on Darfur, discounting flourishing business amidst an underlying continuation of China's support to Khartoum, and arguments prioritizing the benefits of Chinese investment fail to locate this properly within the longer and more recent history of Sudanese politics characterized by a politically and economically dominant centre.

8 For a notable exception, see Sharath Srinivasan, "A marriage less convenient: China, Sudan and Darfur," in Kweku Ampiah and Sanusah Naidu (eds.), Crouching Tiger, Hidden Dragon: Africa and China (Durban: University of Kwazulu-Natal Press, 2008), pp. 55-85.

9 The comparative lack of Chinese scholarship on Sudanese politics until recently reflects history and more generic research constraints. Xu Liang, "Zhongguo de Sudan wenti yanjiu zongshu (19492006)" ("Summary of studies on Sudan issues (1949-2006)"), Xiya Feizhou (West Asia and Africa), No. 2 (2007), p. 71.

10 The historically grounded political foundations of China's modern relations with Sudan, in contemporary political rhetoric conveying a unique, special relationship, is most vividly articulated in the figure of "Chinese" Gordon. He made his name in China, being present when the Summer Palace was sacked in 1850 and serving as commander of the Ever-Victorious Army militia against the Taiping rebels from March 1863. Gordon later served as governor general of the Turko-Egyptian Sudan, famously meeting his death in Khartoum at the hands of Mahdist rebels in 1885. For Premier Zhou Enlai, notably during his state visit to Khartoum in 1964, and for a secession of Chinese political, civilian and military visitors to Sudan, Gordon has symbolized a common experience of shared colonial oppression. In the official narrative, the Sudanese succeeded in exacting revenge on Gordon for China in what is portrayed as an act of just anti-colonial resistance.

11 Reinforcing this idea, the nature and impact of China's post-1989 engagement represents an actual and perceived contrast with previous periods: the role of People's China in Sudan, in which aid and cotton trade were foremost, is generally remembered positively whereas key defining episodes in the latest phase of relations, such as wartime oil operations in Southern Sudan or Beijing's support for Khartoum over Darfur, have had a far more critical reception. See Ali Abdalla Ali, The Sudanese-Chinese Relations Before and After Oil (Khartoum: Sudan Currency Printing Press, 2006); Daniel Large, "Old friend, new actor: notes on the history of Sudan-China relations," Sudan Studies, No. 37 (2008), pp. 39-52. 
discourse of historical, "all-weather" friendship, China has only comparatively recently emerged as Sudan's single most important economic partner and external ally with a more involved political role, as part of a logic of "thickening" engagement that has seen China's position as a "new actor" in Sudan develop and change. ${ }^{12}$

China's relations with Sudan today must be located in relation to the politics and evolution of the National Islamic Front (NIF) regime that seized power on 30 June 1989. This followed a pre-existing pattern of state rule conditioned by the formative historical periods that shaped modern Sudan. The overarching characteristic of political governance bequeathed by colonialism, which would be prominently articulated and practised in the NIF's project of political Islam, is a deep authoritarianism linked to belief in the cultural superiority of those controlling the central state. ${ }^{13}$ Modern Sudan has been governed by a "hyper-dominant but unstable political centre."14 The main regions in Sudan's periphery - the south, east and west - have experienced economic and political marginalization, contributing to a series of interlocking conflicts. These importantly include the protracted armed conflict following rebellion that spread in Southern Sudan after 1983, led by the Sudan People's Liberation Army/Movement (SPLA/M) under John Garang, its commander-in-chief. This conflict would result in over two million deaths, the internal displacement of more than four million people and around half a million refugees. As peace negotiations between the government and the SPLM proceeded, conflict spread in Sudan's western region of Darfur; in short, it was "the war in Southern Sudan speeded up." 15 A particularly intense and devastating government-sponsored counter-insurgency campaign was carried out between 2003 and 2004, following an attack by the rebel Sudan Liberation Army on a government airbase in el-Fasher, Darfur in April 2003. ${ }^{16}$

\section{From Entry to Established Interests: China's Relations with Northern Sudan}

The interplay between the NIF's revolutionary Islamic politics at home and its expansionist ambition abroad created a pattern of recurring crises and adversarial foreign relations. The NIF's own politics would evolve but its difficult early foreign relations set the mould for what was to come insofar as they compounded Sudan's isolation in the Middle East and attracted international pressure. ${ }^{17}$

12 Francis M. Deng, War of Visions: Conflict of Identities in the Sudan (Washington, DC: The Brookings Institution, 1995), p. 383.

13 See Douglas H. Johnson, The Root Causes of Sudan's Civil Wars (Oxford: James Currey, 2003); Justin Willis, "Ambitions of the state," in The Sudan Handbook (London: Rift Valley Institute, forthcoming); see also Peter Woodward, Sudan, 1989-1989: The Unstable State (Boulder: Rienner, 1990).

14 Alex de Waal, "Sudan: the turbulent state," in Alex de Waal (ed.), War in Darfur and the Search for Peace (London: Justice Africa, 2007), p. 20.

15 John Ryle, "Disaster in Darfur," New York Review of Books, Vol. 51, No. 13 (2004).

16 See Julie Flint and Alex de Waal, Darfur: A New History of a Long War (London: Zed, 2008 (2nd ed.)).

17 Including through the regime's most influential figure, Hassan al-Turabi, who supported Saddam Hussein in August 1990 and made efforts to organize and export political Islam. The NIF's terrorist 
The Chinese government was approached for assistance amidst protracted civil war, an American-led containment policy and international sanctions against Khartoum. Regarded as a friendly, resource rich state, Sudan was targeted as a long-term overseas oil supply base and as an arena to support the global development of Chinese corporations. ${ }^{18}$ Bilateral relations deepened in a relatively lowprofile manner, enabled more by circumstances and the unintended consequences of Western foreign policy than any natural political affinity. For China, Sudan was a model site of engagement in Africa predating the expansion of its relations with the continent after $2000 .{ }^{19}$ Bilateral relations were framed in terms of the political facilitation of an economics-in-command model spearheaded by oil investment. This approach, a strong contrast to the confrontation and pressure politics of the United States in particular, suited the NIF perfectly and its leaders placed particular value on China's policy of "no strings or political interference." 20

China's economic relations with Northern Sudan have developed from a comparatively minor position to the country's most important external economic partner. The Chinese commercial expansion in Sudan did not take place in a vacuum but rather entered a political economy in which other external players had been and would continue to be active. ${ }^{21}$ Sudan, however, has become a centre of established Chinese economic interests, which have continued to expand in recent years. Oil remains at the heart of relations and dominates Sudan's trade with China. Sudan was China's sixth-largest oil supplier in 2007, accounting for 6 per cent of China's total crude imports; Sudan has been a key theatre in China's African equity oil investment. ${ }^{22}$ China National Petroleum Corporation (CNPC)-International Sudan operates the largest stakes in the country's two most important oil consortiums, the Greater Nile Petroleum Operating Company and Petrodar, whose main producing blocks are located across the transitional North-South border zone and in Southern Sudan. ${ }^{23}$ Sudan remains

footnote continued

links, most notably the attempted assassination in Addis Ababa of the Egyptian president in June 1995, resulted in the US designating Sudan a state sponsor of terrorism in 12 August 1993. There followed UN sanctions in 1996, US sanctions in 1997 and an American missile attack on a pharmaceutical factory in Khartoum in 1998.

18 Yun Zongguo, "Sudan shiyou kaifa xiangmu qianjing guangkuo" ("Prospects for Sudan oil development project broad"), Guoji jingji hezuo (International Economic Co-operation), No. 5 (1997), pp. 22 23; "Zhongguo gongren zoujin Sudan” ('Chinese workers enter Sudan'), Shijie zhishi (World Knowledge), No. 9 (2004), pp. 42-43.

19 See Linda Jakobson and Zha Daojing, "China and the worldwide search for oil security," Asia-Pacific Review, Vol. 13, No. 2 (2006), pp. 60-73.

20 See Awad al-Jaz, "The oil of Sudan: challenges and achievements," in Peter Gwynvay Hopkins (ed.), The Kenana Handbook of Sudan (London: Kegan Paul, 2007), p. 673.

21 See Daniel Large, "Sudan's foreign relations with Asia: China and the politics of "looking east," ISS Paper 158 (Pretoria: Institute of Security Studies, 2008).

22 See Erica. S. Downs, "The fact and fiction of Sino-African energy relations," China Security, Vol. 3 , No. 3 (2007), pp. 42-68.

$23 \mathrm{CNPC}$ has a 40\% stake in the Greater Nile consortium, which operates blocks 1, 2 and 4 and began exporting good-quality Nile blend crude in August 1999. Output from these blocks declined from a 
China's third largest trade partner in Africa. Total trade has grown steadily, reaching US\$5.7 billion in 2007, with Chinese (manufactured) exports to Sudan growing appreciably over the past decade. ${ }^{24}$ Oil investment has underpinned the subsequent expansion of a more diverse array of Chinese business and a fuller spectrum of business activities. ${ }^{25}$ Economic relations are, however, asymmetrical: in narrow economic terms, China's importance to Sudan far exceeds Sudan's importance to China.

Political and corporate elites have been instrumental in directing bilateral relations. The Chinese government has cultivated effective, close political relations with Sudan's ruling leadership. From the early stages under Jiang Zemin to the deepening of ties under $\mathrm{Hu}$ Jintao, China's political relations have been directed by senior leaders and supported by different branches of government. $^{26}$ Key NCP leaders have been involved in managing China relations. $^{27} \mathrm{~A}$ second area of political co-operation occurs on a party-party basis between the Chinese Communist Party (CCP) and the NCP. This has involved rituals of rhetorical solidarity and more active expressions of support by the $\mathrm{CCP}$ for the $\mathrm{NCP}^{28}$ (also appearing, at times, to entail economic diplomacy ${ }^{29}$ ). The NCP reciprocates through support for Beijing's One China

footnote continued

peak of nearly $300,000 \mathrm{bpd}$ to around $235,000 \mathrm{bpd}$ at the end of 2007 . CNPC has a $41 \%$ stake in Petrodar, whose two blocks (3 and 7) came onstream in April 2006 and in which Sinopec, active in Sudan's downstream sub-contracting, has a 6\% stake. CNPC also has a 95\% stake in Block 6, which produces very poor quality oil mainly for domestic consumption in Sudan. CNPC is an operator of the partly deepwater Block 15 in Sudan and, at the end of June 2007, took at $40 \%$ stake in offshore Block 13. For background, see Luke Patey, "A complex reality: the strategic behaviour of multinational oil corporations and the new wars in Sudan," Copenhagen, DIIS Report, 2006.

24 According to the Bank of Sudan, China's proportion of Sudan's imports have increased from $8 \%$ in 2002 to $20.8 \%$ in 2006. China exports mostly manufactured products to Sudan.

25 Recent growth sectors include telecommunications and agricultural co-operation. In June 2008 a protocol on agricultural co-operation was signed in Beijing by the Sudanese and Chinese Ministers of Agriculture, al-Zubair Bashir Taha and Shen Zhengcai. The construction sector has seen particular increased activity by Chinese companies, notably in infrastructure projects (bridges, roads, railways, dams).

26 Governmental relations are structured into official co-operation channels, with the Joint SudaneseChinese Ministerial Committee, which has alternated between Khartoum and Beijing and held its eighth meeting in Beijing in December 2007, playing a leading role.

27 These, unsurprisingly, represent key members of the NIF, from President Bashir, who first visited Beijing in November 1990, to the role of technical management through the long-term Energy Minister and current Minister of Finance, Awad Ahmed al-Jaz, who played a pivotal role in the oil sector.

28 Seen, for example, in the CCP's message of congratulation and "admiration" to the NCP's general conference in November 2005. Political support for the NCP was notably expressed on 22 March 2009 when vice-minister Li Jinjun of the International Department of the CCP's Central Committee spoke of the CCP's rejection of the International Criminal Court and its ongoing support for Sudan. "Chinese delegation in Sudan for golden jubilee gala," Sudanese Media Centre, Khartoum, 22 March 2009.

29 In December 2008, a CCP "goodwill” delegation led by Chen Jiwa, deputy secretary of the CCP's Guangxi Zhuang Autonomous Regional Committee, visited Sudan at the invitation of the NCP. It held meetings with senior NCP politicians and the governor of the Khartoum State, but also discussed Guangxi's business ties with Sudan. "Sudan, China discuss political and economic relations," Sudan Tribune, 25 December 2008. 
policy and occasional gestures of practical assistance to the CCP. ${ }^{30}$ Military co-operation and arms supplies constitute a third, less documented but nevertheless significant area of state links between China and the Northern government. ${ }^{31}$ A final strand of relations operates between Chinese state-owned enterprises, the NCP and central state ministries in Sudan, in what amounts to a corporate-state nexus that is particularly important in "energy co-operation." 32

\section{The NCP and China: Domestic and External Impacts}

China's engagement has been conditioned most by the political evolution of the NIF/NCP. While the Chinese government has successfully cultivated relations with the NCP, this very entity has also been responsible for the domestic conflict that has been such a source of global political controversy for Beijing arising from its steadfast support of Khartoum. The evolution of - and conflict within - the regime after the 1989 revolution is complex. ${ }^{33}$ The defining event was an internal power struggle in 1999 that saw President Bashir prevail over Hassan el-Turabi, the de facto ruler of Sudan after 1989, as part of a retreat of political Islam and the ascendancy of military rule over that of the Islamist ideologues. ${ }^{34}$ The NCP developed a more pragmatic approach, ${ }^{35}$ together with a powerful security apparatus and an economic base. Its domestic and foreign relations combined to politicize China's role within Sudan and to incorporate Beijing into its foreign relations defence.

30 During a visit by an NCP delegation to Beijing in July 2008, a senior NCP politician, Mustafa Osman Ismail, donated US\$100,000 to the CCP to aid China's response to the Sichuan earthquake. "CCP to promote co-operation with Sudan's National Congress," Xinhua, 9 July 2008.

31 This thickened following an exploratory trip to Beijing by the Chief of Staff of the Sudan Armed Forces in March 2002, but military relations have a longer history dating to 1971 in particular when the PRC assisted President Nimeiri. Different Sudanese sources attribute Chinese technical assistance in building arms factories near Khartoum in the late 1990s, but Sudan's indigenous arms manufacturing capability remains somewhat opaque. On 7 January 2002, the government of Sudan reportedly paraded the hardware produced in its military complex to the public in Khartoum's Green Square. Tanks based on the T-55 - dubbed the Bashir-1, Zubeir-1 and the Abu-Fatima-1 - were showcased. See Daniel Large, "Arms, oil and Darfur: the evolution of relations between China and Sudan," Small Arms Survey Issue Brief No. 7, August 2007.

32 For example, Sudan's current Minister of Energy and Mining, Al-Zubayr Ahmad al-Hasan, visited China in August 2008 at the invitation of CNCP officially to discuss co-operation between his ministry and CNCP. He also attended the inauguration of the Beijing Olympics ("Minister of Energy and Mining visits China," Suna (Khartoum), 12 August 2008).

33 See Alex de Waal (ed.), Islamism and its Enemies in the Horn of Africa (Bloomington: Indiana University Press, 2004); J. Millard Burr and Robert O. Collins, Revolutionary Sudan: Hasan al-Turabi and the Islamist State, 1989-2000 (Leiden: Brill, 2003).

34 See Abdullahi A. Galab, The First Islamist Republic: Development and Disintegration of Islamism in the Sudan (Aldershot: Ashgate, 2008).

35 One China-related illustration of this was demonstrated in 1999 through the "affair of the Chinese loan," which for Einas Ahmed illustrated a willingness by the NCP "to submit religion to reasons of state and sometimes to their own particular interests." Despite Sudan's Islamic banking system, the body charged with oversight of finance with Sharia law invoked a jurisprudence of necessity to allow the government to accept a Chinese loan requiring interest payments. Einas Ahmed, "Political Islam in Sudan: Islamists and the challenge of state power (1989-2004)," in Benjamin F. Soares and Rene Otayek (eds.), Islam and Muslim Politics in Africa (Palgrave, New York: 2007), pp. 189-208. 
Chinese investment and political support has contributed substantially to the NCP's rule, and the resulting close association between China and the NCP has politicized China's position amongst organized armed opponents of the Sudan government. This has drawn Chinese oil operations further into the politics of conflict in Sudan. China's status as a potential proxy in armed anti-state politics was not new. ${ }^{36}$ In contrast to the militarized creation of Sudan's oil export industry in the late 1990s, China's more politicized role occurred in the context of established, functioning oil operations. These expanded after 2005 and fuelled an oil-boom that visibly further concentrated economic benefits in Khartoum, sharpening the discourse of economic marginalization and political domination mobilized by rebel groups in Darfur. Like the SPLA previously, Darfurian rebel groups regard China's role as not just partisan but also politically inseparable from the central state under the NCP and its leaders, the architects of a brutal counter-insurgency campaign in Darfur.

The particular vulnerability to anti-government violence of Chinese oil operations, which are more exposed than other key oil investors from India and Malaysia, has underscored China's deepening political involvement and correspondingly elevated the need for investment protection into a higher priority for Beijing. Two incidents illustrating this are worth noting. In the first significant episode where Chinese interests were explicitly targeted in the context of the Darfur conflict, the Darfurian rebel Justice and Equality Movement attacked Chinese oil operations in Defra, Kordofan in October 2007 and issued an ultimatum to Beijing to withdraw from Sudan within one week. The second, far more serious incident happened in October 2008 when nine Chinese CNPC workers were abducted in Southern Kordofan near the Abyei region, an oil rich flashpoint area in a contested border zone between Northern and Southern Sudan. Five were subsequently killed by forces under a commander claiming affiliation with the Justice and Equality Movement, who had previously fought for the central government against the SPLA before turning against Khartoum. Citing the lack of local benefits from oil wealth and continuing underdevelopment, he asserted that "China supports the Khartoum government militarily and helps it marginalize our region. But our case is with the government in Khartoum." 37 After the incident, the Chinese government despatched an assessment mission led by the Ministry of Foreign Affairs and involving representatives of the Ministry of Commerce and CNPC, ${ }^{38}$ who recommended new measures aimed at enhancing security. Threats and attacks against their own

36 In the late 1990s, amidst the process of oil development that was inseparable from patterns of conflict and civilian displacement in Southern Sudan, the SPLA regarded China as an enemy since it provided political, economic and military support for the government of Sudan. The first incident that clouded China's oil investment came in March 2004 when two Chinese oil workers were kidnapped by antigovernment militia and later released.

37 "Sudan: rebel says Chinese hostages moved to area government forces cannot reach," Al-Sharq al-Awsat website, 25 October 2008 (via BBC monitoring).

38 "Chinese team in Sudan visits four rescued Chinese hostages," Xinhua (in English), 31 October 2008. 
interests provided a self-interested reason for Beijing to promote conflict resolution in Sudan and was one driver of a more active Chinese political engagement.

Largely as a result of changing Sudanese domestic politics, then, what for China had been relatively straightforward bilateral relations facilitating economic investment became entangled in the NCP's foreign relations. The NCP, which has been a far from passive recipient of Chinese assistance, incorporated China into its foreign relations strategy as its key international sponsor. Beijing was willing to support Khartoum for a mixture of reasons related to economic interests and political concerns, notably over sovereignty, and China's support enabled the NCP to pursue a course that would otherwise have been unlikely. However, instrumental in China's mostly reactive policy engagement over Darfur has been the NCP's exercise of political agency, that is, its pursuit of tactical, defensive diplomatic manoeuvring in a path of resistance that at times ran contrary to China's interests, but in which China nevertheless remained vital. The principles that facilitated China's entry into Sudan came to constrain Beijing in the face of an unco-operative NCP under President Bashir that pursued a course of action damaging to China's international reputation. The politics of Darfur in particular required new tactics and political practices that stretched - without, in Beijing's view, contradicting - their meaning.

The Chinese government responded with a more engaged political role featuring continued support for the NCP and pressure upon its senior leaders. China thus maintained and publicly adhered to the formal boundaries of its approach, based upon non-interference and respect for sovereignty, whilst deploying its own form of private influence politics with the NCP leadership. China's use of a strategy of "influence without interference" - a coherent yet ambiguous formulation nicely captures this approach ${ }^{39}$; "China's 'gentle' diplomacy" featured "respect for sovereignty, private persuasion, close consultations." 40 The most prominent area where Beijing engaged in its own form of behind-the-scenes pressure politics was in its support for the deployment of a United Nations peacekeeping mission for Darfur, which ran contrary to the wishes of President Bashir in particular. A second, broad departure from the established norm of China's attitude was demonstrated in the greater willingness of Chinese representatives and senior leaders to express more public, if guarded, criticism of the NCP to the point of featuring prescriptive recommendations for addressing the Darfur conflict. This was epitomized by President $\mathrm{Hu}$ Jintao's four principles for resolving Darfur announced in Khartoum during his February 2007 state visit to Sudan, which noted that "it is imperative to improve the situation in Darfur and living conditions of the people." 41 Beijing's official discourse evolved beyond what had formerly been a state-directed language to encompass civilians: President Hu's

39 Li Anshan, "China and Africa: policy and challenges," China Security, Vol. 3, No. 3 (2007), p. 77.

40 Wang Suolao, "Non-interference and China's African policy: the case of Sudan," report on Symposium on Chinese-Sudanese Relations, 26 July 2007 (London: Centre for Foreign Policy Analysis, 2008), pp. 16-17.

41 "Hu puts forward four-point principle on solving Darfur issue," Xinhua, 2 February 2007. 
comments about the importance of ethnic unity and government responsibility might be taken as a limited transcendence of the state sovereignty doctrine underpinning China's approach. The upshot of these developments was that Beijing appeared to have reasserted its position in relation to the NCP and to have become more willing to resist its demands. This occurred within political constraints and relations formally organized according to the principle of equality but underpinned by asymmetrical power relations. Despite tensions, however, the differences within Beijing-Khartoum bilateral relations should not be overstated. China disappointed senior government leaders in Sudan by not defending Khartoum more robustly (such as in not exercising its United Nations Security Council veto), but despite international pressure the limits of the politically unacceptable were not decisively transgressed and the Beijing Olympics may prove to have been the highwater mark in terms of external pressure upon China's Sudan role.

\section{Negotiating Sovereignty: China's Relations with Southern Sudan}

A state sovereignty doctrine has remained central to the Chinese government's relations with Sudan and its foreign policy defence of Khartoum. Sovereignty, like non-interference, is a reciprocal principle mirroring and projecting abroad China's conception of its desired politics. Apart from limited concern at the role of Chinese companies in Sudan's accelerated, militarized oil development of the late 1990s, ${ }^{42}$ China had not previously been required actively to defend Khartoum and its investment in Sudan, or justify, under scrutiny, its normative support for an absolutist position on sovereignty. China's steadfast support for a hard conception of Sudan's sovereignty and territorial integrity in the controversy surrounding humanitarian intervention in Darfur was in line with, and gave practical meaning to, the sovereignty-based political framework of its Africa policy. Underpinning Beijing's concern at external responses advocating intervention in Darfur has been strong belief in the proper, legitimate role of the central state in maintaining order and avoiding political fragmentation, the importance of political stability and the inherent danger of promoting non-consensual "regime change" from without.

While operative in international politics, the abstraction of sovereignty has not translated easily on to actual politics and shifting patterns of interlocking conflict in Sudan. The result has been a divergence between the legal status of sovereignty and its "empirical" political manifestations. ${ }^{43}$ While the central state in Khartoum has concentrated political power and wealth it has also suffered from an underlying weakness of central rule, meaning that it cannot maintain control over its full territory and over time has had to make repeated attempts to co-opt local authority

42 See Human Rights Watch, Sudan, Oil and Human Rights (New York: Human Rights Watch, 2003).

43 Robert H. Jackson, Quasi-states: Sovereignty, International Relations and the Third World (Cambridge: Cambridge University Press, 1990). 
in order to pursue its objectives. ${ }^{44}$ The marked incongruence between state sovereignty as a juridical-political phenomenon and the reality of contested authority amidst protracted armed conflict has forced Beijing to respond to the fact that the central state in Khartoum is unable to exert effective control over its full territorial jurisdiction. ${ }^{45}$ Beijing has thus had to negotiate and adapt to the politics manifest beyond and below formal central state sovereignty, which in practice means engagement with Sudan's periphery and most notably Southern Sudan.

\section{One Country, Two Systems: Sudan after the 2005 Peace Agreement}

The Comprehensive Peace Agreement (CPA) of January 2005 between the NCP and the SPLM formally ended the North-South war, which had lasted for 22 years. International attention to Darfur had overshadowed Sudan's NorthSouth political axis and also meant that Beijing's incremental steps to develop relations with and invest in Southern Sudan, a much less prominent but nevertheless important evolution, was neglected. Given that the Chinese government faithfully dealt with governments in Khartoum between 1959 and 2005, this has entailed a departure from Beijing's hitherto exclusive relations with the central state. ${ }^{46}$ Relations that developed between China and the SPLM-led Government of Southern Sudan after 2005 thus represent a political departure of note in the history of its relations with Sudan. This development is an underlying reflection of the constraints of adhering to a strict policy of respecting formal state sovereignty as well as the political complexity involved in maintaining economic interests in Sudan.

The CPA instituted different systems in Northern and Southern Sudan, establishing two governing entities as part of a six-year interim period: a Khartoum-based Government of National Unity operating on a power-sharing basis between the NCP and the SPLM, and the semi-autonomous regional Government of Southern Sudan based in the new southern capital of Juba under control of the SPLM. The agreement also included a wealth-sharing provision, which enabled Southern Sudan to receive a share of oil profits. The most politically significant provision of the agreement, however, is its assertion "that the people of South Sudan have the right to self-determination, inter alia, through a referendum to determine their future status." The CPA stipulates that such a referendum will be staged in 2011 "for the people of South Sudan to: confirm the unity of the Sudan by voting to adopt the system of government established

44 Conflict in Darfur is a recent manifestation of a historical pattern of the state's mobilization of proxy militia, following the deployment of this tactic in the war in Southern Sudan.

45 See Christopher Clapham, "Fitting China in," in Chris Alden, Daniel Large and Ricardo Soares de Oliveira (eds.), China Returns to Africa (London: Hurst, 2008), pp. 361-69.

46 Beijing did not support Anyanya 1, the earlier Southern Sudanese rebellion that ended with a peace agreement in 1972, which might have been viewed by the PRC as a worthy people's struggle. This was in contrast to its support for "revolutionary armed conflict" in other parts of Africa. Beijing continued to support Khartoum, having apparently concluded that any other policy would jeopardize relations with a friendly government and China's wider interests in the Middle East. 
under the Peace Agreement; or to vote for secession."47 The SPLM's official position has been to support its constitutional obligation to "make unity attractive," although opinion is divided on the issue of secession. ${ }^{48}$ Since 2005, Southern Sudan has effectively been "operating as a quasi-independent state." 49

China's relations with Juba can be said to fall under the principle of "one Sudan, two systems" in recognizing and engaging Sudan's central Government of National Unity and the Government of Southern Sudan. ${ }^{50}$ As recommended in a report published in 2001, this formula proposed an interim political arrangement of a single united Sudan involving "two, viable, self-governing democratic regions, north and south." 51 Enshrined in the CPA, this allowed the historic problem of Southern Sudan's position within Sudan to be addressed and politically accommodated. ${ }^{52}$ The formal, legal incorporation of the SPLM into the central Government of National Unity rendered it politically and legally possible on paper for Beijing - like other foreign governments from Africa and beyond to engage the SPLM and Juba directly. By conferring political legitimacy upon the SPLM as members of the central state and as the former-rebels turned ruling party of the Government of Southern Sudan, the CPA therefore enabled but also required Beijing to embark on a process of incremental political outreach with Juba.

Even if China's relations with the SPLM were legally sanctioned within the terms of the CPA, political outreach with Southern Sudan presented particular challenges for Beijing due to its previous wartime political, economic and military support for the central government in Khartoum. China had not dealt with the SPLM before in any formal capacity; its support for the NIF/NCP meant that it was widely seen as the principal backer of the SPLA/M's former enemy. What Beijing presented as non-interference in Sudan's internal affairs was interpreted by the SPLM in quite different terms: as interference through support for its enemy. Nevertheless, the conjunction of time-honoured pragmatism, mutual need and the prospect of mutual benefit meant that both the Chinese government and the Government of Southern Sudan were open to business after 2005. The SPLM's post-war China policy was premised on constructive engagement and working with former enemies. ${ }^{53}$ After devastating conflicts, Southern Sudan's need for investment was considerable. The scheduled referendum, coupled with

47 Comprehensive Peace Agreement (2005), p. 4, para. 2.5. Full version at www.sudanarchive.net.

48 Popular Southern sentiment tends to support the vision of independence more than the SPLM's John Garang-inspired vision of a united, reformed and democratic "new Sudan."

49 Peter Adwok Nyaba, "An appraisal of contemporary China-Sudan relations and its future trajectory," paper presented at the Centre for Advanced Studies of African Societies, 23-24 November 2005.

50 China is not alone in doing so, with other foreign governments from Africa and beyond doing the same.

51 "US policy to end Sudan's war: report of the CSIS task force on US-Sudan policy," co-chairs Francis M. Deng and J. Stephen Morrison (Washington, DC: CSIS, February 2001).

52 This principle appeared to have been inspired by Deng Xiaoping's recommendations in 1984 for a practical means to accommodate socialist China's relations with capitalist Hong Kong, Macau and Taiwan.

53 Conversations with senior SPLM leaders, Juba, December 2005. 
the geography of CNPC's main oil fields, most influenced Beijing's need to respond to the new political reality in Juba.

\section{Emerging Links: China's Relations with Southern Sudan}

A progressive strengthening of relations between Juba and Beijing unfolded after 2005, resulting in the Chinese government establishing quasi-diplomatic relations with the Government of Southern Sudan in 2008. The first official contact between Beijing and the SPLM was made when a high-ranking SPLM delegation visited Beijing in March 2005 to discuss possible "economic co-operation." The delegation was led by Salva Kiir Mayardit, who was second-in-command to John Garang and vice-president of Southern Sudan at the time. Following Garang's unexpected death four months later on 30 July 2005, he became First-Vice-President of Sudan and President of Southern Sudan. Subsequent further contacts of note included a meeting between Salva Kiir and President Hu Jintao in Khartoum in February 2007 and a state visit by Salva Kiir to China in July 2007 where he wore two political hats: the official second highest political position within Sudan's Government of National Unity, and leader of Southern Sudan. The process whereby official ties were established was confirmed when China's new consulate in Juba was inaugurated at a ceremony attended by Assistant Foreign Minister Zhai Jun on 1 September 2008. This move formalized the new diplomatic axis between Juba and Beijing, allowing China to engage Southern Sudan in its own, bilateral terms rather than having relations mediated through Khartoum.

Beijing's relations with the Government of Southern Sudan subsequently deepened - through aid ${ }^{54}$ and expanded investment ${ }^{55}$ - and broadened to encompass other political actors. A less developed but growing area of political engagement has been CCP-SPLM party-party co-operation. The SPLM secretary general, Pagan Amum, reported that during Salva Kiir's 2007 trip to China, the CCP invited the SPLM to establish party-party links and that the SPLM planned "to establish relations" with the CCP in order "to ensure efficient development

54 China's aid to Southern Sudan was to be increased following an official Chinese needs assessment mission to Juba in mid-2007. A number of projects, from hydropower to road construction, were planned. In early April 2009, the Chinese Consul General in Juba donated a grant of \$100,000 to the Government of Southern Sudan from Beijing.

55 An expanded Chinese commercial involvement is a further dimension of Chinese engagement with Southern Sudan. There had been little of substance beyond Chinese oil operations prior to 2005 but the CPA opened up a new frontier of business opportunity. At first Chinese construction work was prominent in Juba. Chinese companies entered via Kenyan and Ugandan brokers in the form of private joint ventures. The Nile Construction Company, for example, entered into a joint venture with the Chinese company Golden Nest in October 2006 to work on construction projects. The China National Overseas Engineering Company renovated government buildings and the Juba Teaching Hospital for the Government of Southern Sudan. A small Chinese service sector subsequently developed. This featured the prefabricated Beijing Juba Hotel, which suffered fire damage in February 2009, and the "Wonderful Chinese Restaurant" established by a Chinese businesswoman from Wenzhou who had identified an open market. Conversation in Juba, 18 June 2008. China's actions impressed elements within the Government of Southern Sudan by swift, effective delivery of infrastructure, a contrast to the slow-turning wheels of the multilateral assistance framework. 
and management of oil resources to the benefit of the Sudanese people."56 Chinese political and corporate relations with Southern Sudan have not been confined to the Government of Southern Sudan in Juba but have also featured connections with state authorities. An example of engagement by an oil-rich Southern Sudanese state with the Chinese government and CNPC happened in August 2008 when the governor of Upper Nile State, ${ }^{57}$ Gatluak Deng Garang (an NCP representative), made an official visit to China. He met Chinese government representatives, visited CNPC and sought to negotiate expanded Chinese investment in Malakal, the state capital. ${ }^{58}$

China's engagement aims to support Juba and promote China's position in Southern Sudan. It has acted in part to address its acknowledged unpopularity and gain a more strategic political foothold in Southern Sudan. It remains questionable, however, how far China's relations with governing political elites in Juba can overcome continuing widespread grievances amongst communities in oil-producing regions of Southern Sudan. Local grievances are not confined to Chinese oil companies. While most immediately directed toward oil companies and their operations, grievances express more general frustrations at the lack of a tangible "peace dividend" and compensation for the wartime impact on civilians of oil development. ${ }^{59}$

China's links with Juba contrast with the way in which relations had developed with Northern Sudan after $1989 .{ }^{60}$ In the earlier period, resource imperatives and investment opportunity were paramount. While state-backed and facilitated through political means, this was a commercially driven entry into a new theatre. In engaging the Government of Southern Sudan, however, Beijing responded to political imperatives flowing from investment protection concerns produced by established interests as part of an apparent hedging strategy geared toward the possibility of Southern secession. China's engagement has been successful in improving relations with the Government of Southern Sudan and the SPLM, establishing a foothold in Juba and opening up a new business frontier. Like other external actors, it remains subject to the continuing constraints and myriad problems facing the Government of Southern Sudan. These range from the institutional challenges involved in building a functioning, capable system of government, to fiscal crisis resulting largely from massive dependency on oil revenue, ${ }^{61}$ as well as infrastructure needs and continuing and new "south-south" conflicts.

56 Organizational Report Presented to the Second National Convention of the Sudan People Liberation Movement by SPLM Secretary-General Pagan Amum Okiech, 18 May 2008.

57 The state in which Petrodar concessions are located.

58 CNPC appeared keen to co-operate with Upper Nile state authorities, and would, through the Petrodar consortium, contribute infrastructure projects to Malakal, which demonstrated business relations between the foremost Chinese oil company in Sudan and a state government.

59 See Leben Moro, "Oil, conflict and displacement in Sudan," DPhil thesis, University of Oxford, 2008.

60 Thanks to Laura James for pointing this out.

61 Oil accounted for roughly $99 \%$ of total Government of Southern Sudan revenues in 2006 and over $98 \%$ in 2008. See "Government of Southern Sudan. 2009 budget speech," Kuol Athian Mawien, Minister of Finance and Economic Planning, presentation to the Southern Sudan Legislative Assembly, 10 December 2008 . 


\section{Conclusion}

The golden jubilee celebrations ended on 22 March 2009 in Khartoum's Chinese-built Friendship Hall. Amidst rhetoric about the bright prospects for future relations, the festivities had been tantamount to a celebration of the past two decades of China's relations with the NIF/NCP. Over this period, the politics of China's Sudan engagement became more complicated with the development of a "thicker," more embedded and consequential Chinese role within Sudan. Due to a combination of Sudan's recent salience in China's foreign relations and its changed politics in different parts of the country, China's interests evolved beyond resource extraction or business concerns. Beijing had developed two main interconnected processes of engagement amidst ongoing conflict in the western region of Darfur and the new political geography of Sudan's North-South formal peace. Having developed vested interests in the political stability of the central state, peace in Darfur, the fledgling Government of Southern Sudan and, overall, in the success of the CPA, China evolved a "comprehensive approach" to Sudan. ${ }^{62}$ Given the strong potential for Chinese oil companies and CNPC in particular to be negatively affected by renewed armed conflict in Southern Sudan through a terminal breakdown of relations between the NCP and the SPLM, the political guarantors of the CPA, Beijing's priorities became more concerned with investment protection imperatives rooted in political stability and preserving the North-South peace. The extent to which the Chinese government can or is inclined to play a more engaged role in protecting the CPA, however, and in particular to mobilize its influence politics with the NCP on core issues in CPA implementation, is questionable but remains a subject of some significance in Sudan's political future.

The fundamental challenge faced by China in relation to its Sudan engagement was the nature and prospects of the central state under the NCP. Because it confers prior legitimacy upon a partner state's actions, even in cases like the extremes of violence unleashed in Southern Sudan and Darfur, China's official approach will almost by definition be necessarily reactive. Sudan has tested the limits of this approach. While China and Sudan's respective and mutually understood national interests were subjected to strain, divergent interests were effectively managed in a process that demonstrates the continuation of robust bilateral ties amidst wide international controversy and negative impact on Beijing's reputational concerns. Conflict in Darfur continued in 2009 and the prospects of a political resolution are poor. The scheduled referendum on Southern Sudanese secession, in which the outcome most desired by many Southerners is an independent state, is fundamental to the political future of Sudan. This historic scenario remains fraught with attendant danger and political contestation. Beijing has succeeded in developing the basis of political relations with Juba but the extent to

62 As well as continued peacekeeping support, Beijing also made public statements on the CPA and support gestures, such as a donation of US\$3 million to the NCP to support the CPA in late 2008. 
which its new relations with the SPLM will prove strong enough to withstand a return to open conflict between Northern and Southern Sudan is questionable.

Aspects of China's experience in Sudan are more broadly applicable, in different ways, to its African role. The first concerns the political agency of African states and other actors, and how this affects China's politics within different states as well as its foreign policy impact, including on relations with more established powers, most importantly the United States. A related issue is how tensions created by the distance between China's formal principle of sovereign equality and the actual asymmetry of power relations are managed when confronted with divergent interests of consequence. A second, and connected, issue is how the central Chinese government and national oil companies, in this case, manage relations with different "non-state" actors in Sudan (not to mention the role of transnational actors). In the broader scheme of its African experience, China's relations with the quasi-sovereign Government of Southern Sudan mark an interesting departure even if these are consistent with a legally sanctioned political arrangement. Chinese oil companies have been caught up in and remain vulnerable to renewed conflict as a more exposed potential target for groups seeking to apply leverage against Khartoum by targeting its strategic allies. This begs the thorny question of how China's investment protection imperatives, which in Sudan have been produced by over a decade of economic engagement, can in practice be reconciled with adherence to a faithful operationalization of the principle of non-interference.

Sudan offers a salient case of a more widespread deficiency in approaches to China's relations with Africa to date in terms of how China's engagement is involved in and relates to African politics. While a subject that has attracted wide reactions in relation to governance concerns, in general this has yet to receive the in-depth treatment its growing importance deserves. As the single most controversial relation in China's recent, most visible and potentially consequential rise in Africa, Sudan has often been misleadingly elevated in monolithic representations of China's entire continental engagement despite bearing its own specificities. It nevertheless remains an important case, partly because China's involvement predated the acceleration of its wider African engagement and as such provides an illustration of the importance of politics in conditioning China's experience over time, but also due to the changing nature and trajectories of its political role. How the shifting constellation of actors grouped under the phrase "China" relates to, and affects, politics in Sudan and the African continent more generally, and how an expansive engagement is shaped by African politics and influences China's international politics, looks set to remain inescapable and important. 